\title{
Digital Health Strategies to Fight COVID-19 Worldwide: Challenges, Recommendations, and a Call for Papers
}

Guy Fagherazzi, MSc, PhD; Catherine Goetzinger, MSc; Mohammed Ally Rashid, MD; Gloria A Aguayo, MD, PhD; Laetitia Huiart, MD, PhD

Luxembourg Institute of Health, Strassen, Luxembourg

Corresponding Author:

Guy Fagherazzi, MSc, PhD

Luxembourg Institute of Health

1 A-B Rue Thomas Edison

Strassen, 1445

Luxembourg

Phone: 35233669396334

Email: guy.fagherazzi@lih.lu

\begin{abstract}
The coronavirus disease (COVID-19) pandemic has created an urgent need for coordinated mechanisms to respond to the outbreak across health sectors, and digital health solutions have been identified as promising approaches to address this challenge. This editorial discusses the current situation regarding digital health solutions to fight COVID-19 as well as the challenges and ethical hurdles to broad and long-term implementation of these solutions. To decrease the risk of infection, telemedicine has been used as a successful health care model in both emergency and primary care. Official communication plans should promote facile and diverse channels to inform people about the pandemic and to avoid rumors and reduce threats to public health. Social media platforms such as Twitter and Google Trends analyses are highly beneficial to model pandemic trends as well as to monitor the evolution of patients' symptoms or public reaction to the pandemic over time. However, acceptability of digital solutions may face challenges due to potential conflicts with users' cultural, moral, and religious backgrounds. Digital tools can provide collective public health benefits; however, they may be intrusive and can erode individual freedoms or leave vulnerable populations behind. The COVID-19 pandemic has demonstrated the strong potential of various digital health solutions that have been tested during the crisis. More concerted measures should be implemented to ensure that future digital health initiatives will have a greater impact on the epidemic and meet the most strategic needs to ease the life of people who are at the forefront of the crisis.
\end{abstract}

(J Med Internet Res 2020;22(6):e19284) doi: 10.2196/19284

\section{KEYWORDS}

coronavirus; COVID-19; digital health; eHealth; digital technology; health care; surveillance; communication; review; epidemiology; infodemiology; public health

\section{Background}

Countries around the world have been affected by the COVID-19 pandemic since December 2019 [1], and the health care systems in these countries are rapidly adapting to the increasing demand. The World Health Organization (WHO) has called for coordinated mechanisms to support the response to the outbreak across health sectors, and digital health solutions have been identified as one of the most promising approaches to address this challenge in modern societies [2].

The COVID-19 pandemic is singular in many ways. First, in terms of number of people infected, transmissibility, and spectrum of clinical severity, it has had a greater impact to date than previous epidemics such as pandemic influenza, Middle
East respiratory syndrome (MERS), severe acute respiratory syndrome (SARS), or Ebola virus [3]. Second, COVID-19 can be considered as the first true global epidemic of this magnitude in the digital era; digital health solutions, which have reached a certain level of maturity but are not widely deployed and accepted yet, can play a major part in our response to the crisis [4]. Indeed, the COVID-19 pandemic is occurring in an era of massive technological advancement. Digital tools can effectively support institutions during a pandemic by facilitating the immediate widespread distribution of information [5], tracking transmission in real time, creating virtual venues for meetings or day-to-day operations, and providing telemedicine visits for patients [6]. However, some digital health strategies and tools may face challenges associated with barriers to access, acceptability, and ethical issues. For instance, some governments 
worldwide are responding to this public health emergency with an unprecedented array of surveillance tools designed to identify and track people who may be infectious [7]. These measures have escalated existing debates regarding individual privacy and government oversight of private citizens.

The COVID-19 pandemic is providing a starting point to discuss how digital health solutions can and should be leveraged to address this unprecedented crisis [8]. This editorial offers an overview of the digital health strategies that have been employed worldwide to fight COVID-19 to date as well as a discussion of the challenges to developing more meaningful [9] and ethical solutions in the near future.

\section{Digital Health Care Models}

New health care models are needed during the COVID-19 pandemic. Due to the high transmission rate of COVID-19, most countries have ordered strict lockdowns; hence, patient-physician communication and visits are challenging. In the era of digital health technologies, the focus on new models has shifted to telehealth (virtual visits, virtual care), mobile apps (remote patient monitoring), and websites and chatbots (risk assessment, screening, triage). Figure 1 describes the main stakeholders at the forefront of the COVID_19 crisis (the population, the health care systems, and the research and health technology environment in coordination with public health agencies or governments) with significant illustrations of efficient digital health strategies that have been implemented to date at various levels.

Figure 1. The COVID-19 digital health ecosystem. AI: artifical intelligence; e-prescribing: electronic prescribing; tech: technology.
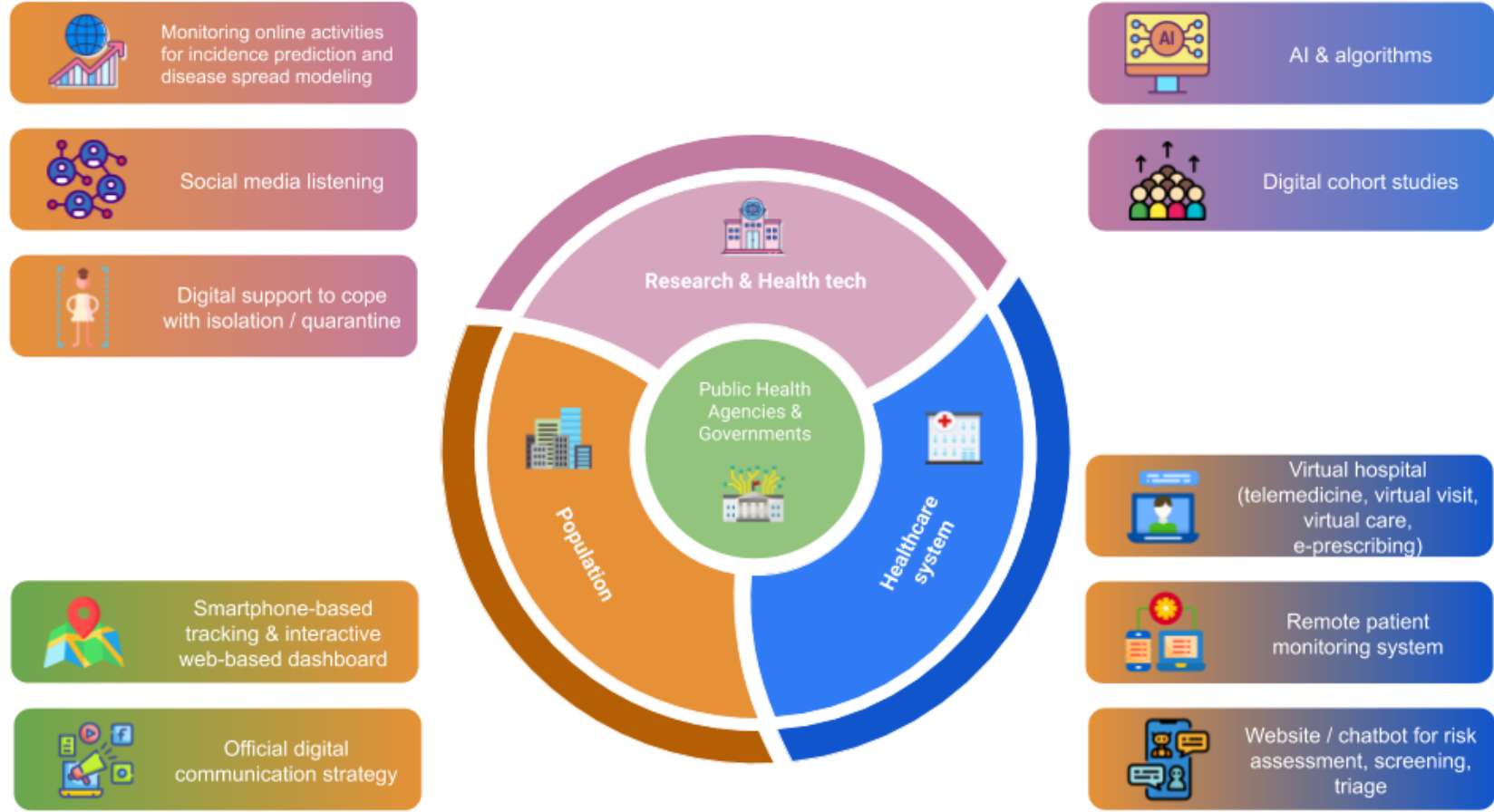

\section{Telemedicine and Remote Patient Monitoring Systems}

Telemedicine allows patients to receive care at home [10], thus avoiding the spread of COVID-19 in overcrowded emergency or waiting rooms [11]. Telemedicine not only supports secured care for COVID-19 patients but also allows routine primary care and electronic prescriptions (e-prescriptions). In addition, health care professionals can screen and monitor symptoms in real time, provide useful medical advice when needed, and keep stable patients at home away from overloaded hospitals [12].

Additionally, these tools can serve as useful resources to rapidly collect meaningful information on large cohorts of patients to study the evolution of their symptoms in real time; this increases understanding of the different clinical phenotypes of people infected with COVID-19 and enables the study of its long-term health consequences. Such a prospective cohort was recently established in Luxembourg (Predi-COVID) to study factors associated with COVID-19 disease severity; this study uses data from the national telesurveillance system that is used for virtually all patients who tested positive for COVID-19 and combines the data with biological sampling, electronic patient-reported outcomes, and innovative digital data collections such as smartphone-based voice recording to identify vocal biomarkers of respiratory syndromes. In another study, Wang et al [13] described armband sensors that can remotely measure the accuracy of hand hygiene based on WHO procedures.

\section{Triage and Risk Assessment}

The COVID-19 virus has caused panic and uncertainty within populations; to ensure better allocation of resources, telemedicine based on videoconferences can be used not only to comfort patients but also for triage [14]. Hollander et al [15] 
highlighted that telemedicine can serve as a triage system in different phases. The first stage is "forward triage;" here, patients are categorized as possibly COVID-19 infected or uninfected before they arrive at the hospital. In addition, telemedicine ensures close monitoring of less severely infected patients at home by allowing communication around the clock. The second phase of triage occurs in the hospital and is referred to as the "provider-in-triage model." In this phase, patients at high risk for COVID-19 are screened by rapid evaluation of clinical characteristics and testing. Patients are kept in isolated emergency rooms, where they are given tablet devices to communicate with professionals [15]; the tablets are cleaned between patients. To reduce risk of infection among health care professionals, hospitals have also implemented electronic intensive care unit monitoring. For example, a few countries have launched within-hospital telemedicine programs. A robot enters the room of a patient infected with COVID-19 to monitor both vital and cardiac signs and enable communication between the patient and health care professionals where applicable. All the robot's actions are controlled by nurses or physicians outside the room [16]. Figure 2 shows the typical path of an individual from the time they have questions about their health or symptoms potentially related to COVID-19. Digital technologies now enable online symptom checks, video consultations, and e-prescriptions and allow forward triage instead of overloading hospitals and increasing the spread of the virus. Low-risk patients can be regularly monitored from home, whereas patients with more severe symptoms can be monitored at hospitals with a provider-in-triage using digital tools.

Figure 2. Risk assessment and triage of COVID-19 in a digital health care model. COVID-19: coronavirus disease.

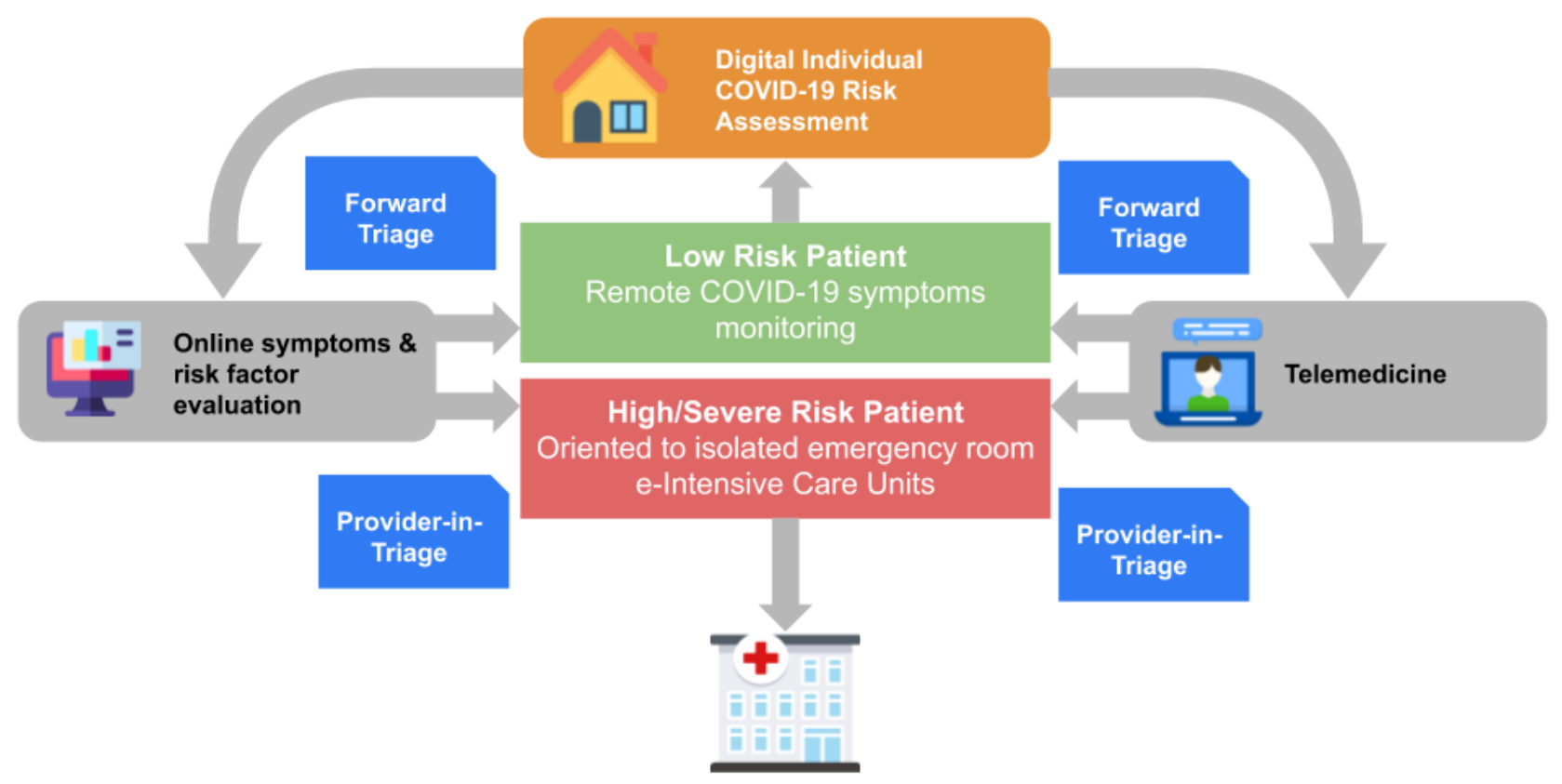

Web-based symptom trackers such as maladiecoronavirus.fr [17] in France and beatcovid19now.org [18] in Australia were rapidly established to help individuals assess their risk for COVID-19; these trackers are being updated as knowledge of COVID-19 evolves. Site users must answer several questions to feed the risk prediction algorithms; then, based on risk stratification, the website advises the user to call a hotline to receive further instructions or to stay at home and follow international guidelines. Similarly, chatbots such as Symptoma are systems that digitally assist individuals in performing risk assessment of COVID-19 [19].

\section{Digital Communication During the Pandemic}

Communication between political leaders and scientific authorities is crucial during a pandemic crisis [20] (Figure 3). Since the start of the COVID-19 pandemic, disinformation, "fake news," and conspiracy theories about the origin, spread, and treatment of the disease have been present on the internet and in government communications, social media, and SMS text messages. These communication problems also cause confusion and mistrust; the consequences are negative at both the individual and community levels. To provide the most useful information in a timely fashion, effective digital risk communication has been established internationally by WHO as well as nationally and regionally through an active factual information campaign using several digital channels. Good communication strategies help manage people's fear and increase the likelihood that they will adhere to the measures imposed on them during the crisis. Risk communication promotes community engagement, avoids or decreases the profusion of rumors, and reduces threats to public health. However, poor risk communication can create a great deal of confusion, frustration, and future mistrust of leaders. Communication in epidemics must not only be clear and unambiguous but must also reach the target population quickly (health workers, local authorities, and the public). For instance, guidelines around 
practicing social distancing have been judged to be unclear and prone to misunderstanding. These guidelines should be followed with more direct messages, such as "stay at home," especially to clarify the concept of social distancing for vulnerable populations or younger people. The WHO webpage uses the phrase "physical distance" in addition to "social distance" to emphasize this necessity. However, social contact must be

Figure 3. Communication risks and strategies during disease outbreaks. stimulated, especially for older persons [21]. Digital methods appear to be promising solutions, as they enable people to maintain physical distance while keeping informed or maintaining contact with others; for example, the WhatsApp messaging platform provides health alerts in different languages [22].

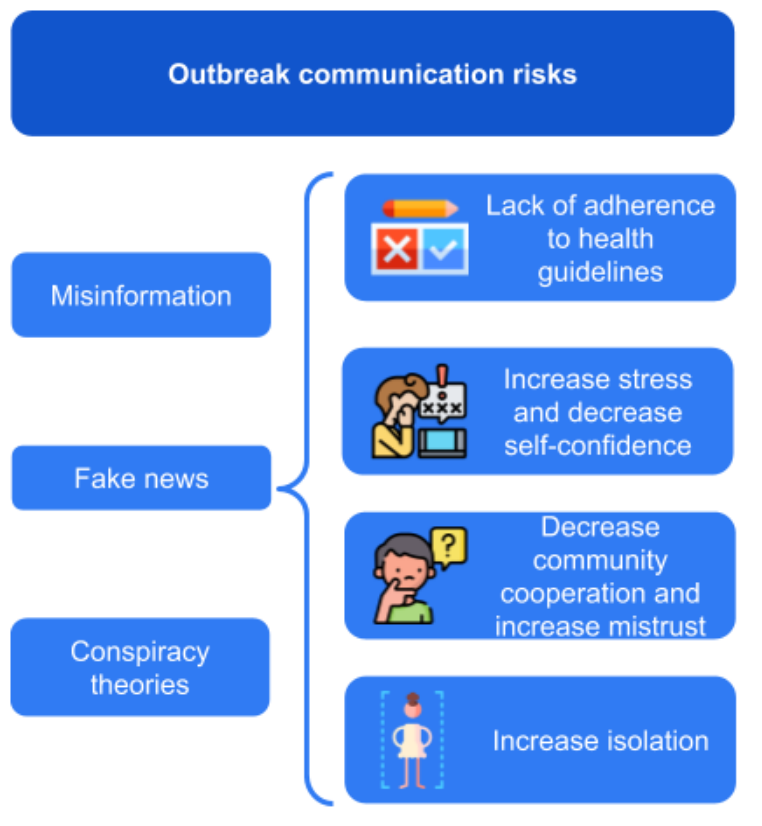

In addition, digital health can play a major role at a governmental level. Government initiatives have been taken to provide guidelines and information on government websites to inform the population about appropriate behavior during the lockdown period, hand hygiene, etc. Most of these initiatives were supported by international guidelines from WHO or the US Centers for Disease Control and Prevention (CDC).

The use of apps or instant messaging services to enable ministries or health agencies to contact health workers remotely and to inform government officials about the number of cases, symptoms, and prevention measures are just a few examples of measures that have been efficiently used in previous pandemics [23] or early in the COVID-19 crisis [22]. A crucial consequence of a bad risk communication strategy is the likelihood of increased levels of anxiety within the population. Contradictory information and overexposure to sensationalist headlines from mass media and social media can affect people's mental health and increase the general level of fear. Lockdown can amplify the problem due to increased exposure to social media and rumors as well as lack of confrontation of ideas and debate in the real world [24]. Consequently, lockdown reinforces the importance of institutional development of digital strategies. Therefore, during the outbreak, official communication plans should promote easily accessible and diverse channels of digital communication at all stages and for different purposes (global, regional, and community-based communication). These channels should be integrated as an information system, as a
Leverages for an efficient digital crisis communication

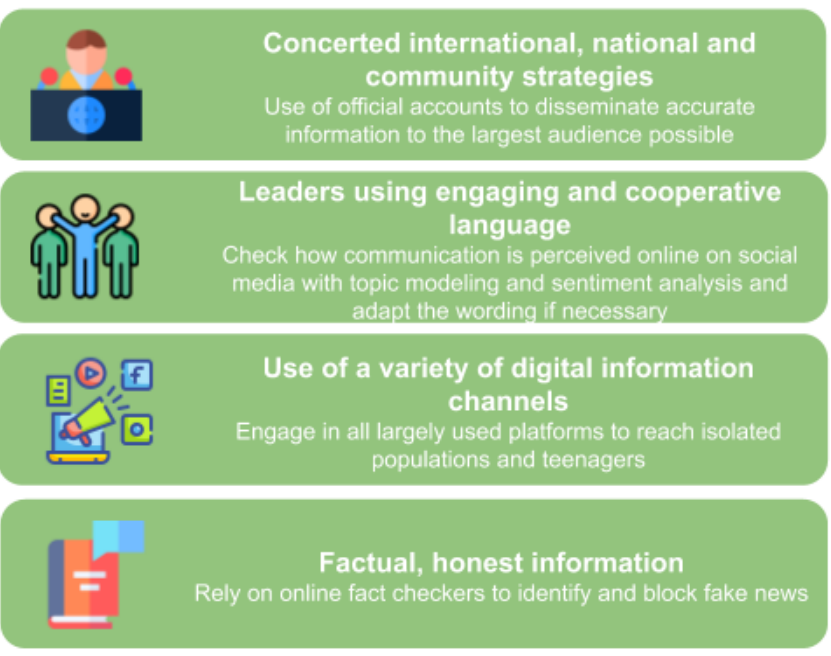

communication tool, and for detecting and supporting people at risk [25]. An example of a communication strategy that was developed very quickly and effectively to fight fear and rumors among a population is the sending of messages by the government of Singapore through WhatsApp [26]. Finally, a strategy to include marginalized and vulnerable populations should be planned. Such a strategy should involve establishing multiple means of communication, including digital platforms; using adequate, simple, and nondiscriminatory language; and taking differences in health literacy into account [27].

\section{Digital Data to Model COVID-19 Spread, Evolution, and Perception}

The monitoring of online or social media activities for public health purposes has been investigated since the first days of the digital epidemiology field in the early 2010s, with the objective of capturing health-related trends and modeling disease outbreaks. The most famous examples of internet health surveillance were developed to predict the incidence of influenza, such as Google Flu Trends, or to obtain insights from social media platforms such as Twitter about influenza A/H1N1 [28], measles [29], the Zika virus [30], and the Ebola virus $[31,32]$. Despite their high potential in public health, these studies have been criticized for their lack of theorization and appropriate standard methodology [33], which can prevent comparison of their results and raises questions regarding the 
safety of relying on their findings to design targeted public health measures in the real world. To move beyond the simplistic thought that Twitter is a "giant playground" for data scientists, ongoing initiatives to use Twitter data to study the COVID-19 outbreak should build upon previous mistakes, with a more rigorous approach as well as an open source/open data mentality.

Online activities are very good indicators of trends in society. Exploiting data such as Google Trends [34], Wikipedia searches, or the Baidu Index and Weibo Index in China has already proved useful. In China, internet searches and social media data related to COVID-19 have been shown to be highly correlated with daily disease incidence and exhibit an online peak 10 to 14 days before the peak of daily incidences in the real world [35]. Although there are few reports to date, such data sources could also prove useful for early identification of less common symptoms related to COVID-19 using a similar approach to that used to detect weak pharmacovigilance signals from social media and identify side effects of drugs [36]. The main advantage of these data sources is that they can be accessed early in the epidemic and at low cost.

However, predicting disease incidence from online activities or social media data has never been used in a real time prospective fashion for public health guidance on a large scale; rather, such predictions are performed retrospectively by training algorithms to replicate gold-standard data, such as those obtained from the CDC [37], as closely as possible. COVID-19 may be the first outbreak where such a prospective analysis occurs, combining data from standard sources of disease surveillance with social media data or activity trackers [38] to improve overall accuracy.

Social media data analysis is also relevant during the COVID-19 outbreak to monitor how people react to the pandemic evolution over time (sentiment, anxiety, level of stress) as well as common beliefs, opinions [39,40], fears, or hopes regarding treatment or vaccines. Perhaps most importantly, identifying and combating the spread of "fake news" about COVID-19 is highly necessary in our modern digital society $[41,42]$. This could help to rationalize the debates and actions around COVID-19 and should be further extended [43].

\section{Discussion}

\section{Challenges Related to Digital Health Implementation}

The COVID-19 crisis is a typical example of the impossibility of establishing a single global technological solution to a given problem. To increase acceptability of digital technologies, the different cultural, moral, and religious backgrounds of users should be considered. With priority given to collective public health benefit and maintaining local social order during the current emergency [44], digital measures can be intrusive and can erode individual freedoms. In some countries, a strong digital divide persists today, and vulnerable populations may be overlooked during the implementation of digital approaches [45-47]. Digital solutions may be less frequently understood and used by people with low health literacy levels or by specific subgroups such as minorities, older individuals, or people who live in rural or low-income areas [48]. For all these reasons, digital approaches can be received in very different ways when they are applied in high-income, medium-income, or low-income areas or when they are deployed in individualistic versus collectivistic countries [49].

In Singapore, an app called TraceTogether has been used to track patients infected with COVID-19. Based on Bluetooth signaling, Singaporean health authorities can track individuals and inform them if they have been in contact with a patient infected with COVID-19 [50]. This patient monitoring system may be beneficial in disease surveillance and outbreak management; however, in European countries, it would not be possible to use it due to individual data protection laws. France conceived the CoronApp, which is based on similar standards [51]. Individuals need to register on the app and provide information on their health status and whether they have symptoms. A geolocation system is used to trace this information and is updated every hour. King's College London conceived the COVID Symptom Tracker app, which aims to help patients monitor their own symptoms [52]. The app gained such popularity that it is now also used in the United States. In addition to its individual benefits, the app can be used for research purposes to study the epidemiology of COVID-19.

Urged by the European Commission, an unprecedented consortium of eight giant telecommunications companies recently agreed to share aggregated and anonymized geolocation data from their clients to track their movements and activities. This raises numerous questions around data privacy [53] and ethics in Western and African countries [54], despite the availability of privacy-preserving proximity tracing technology such as the Decentralized Privacy-Preserving Proximity Tracing (DP-3T) protocol [55]. In Asia, the response to the COVID-19 crisis in South Korea has received much attention and has been widely cited as an exemplary model. With the increased flexibility in South Korea's digital privacy laws since the MERS crisis in 2015, numerous aggressive digital solutions have been used, such as a national smartphone app, GPS tracking of infected people, and detailed emergency alerts when a positive case has been identified in a person's geographical area. However, it was proved that this approach was only efficient to reduce the number of new daily cases due to a vast parallel testing campaign to identify COVID-19 hotspots combined with strong isolation and quarantine measures. In Europe, where testing is not as widespread as in South Asia, the use of such monitoring using GPS coordinates is therefore ethically questionable.

Regarding telehealth, the challenge of implementing feasible systems lies with governments in most cases [56], as billing systems must be adapted [15]. Telemedicine consultations must also ensure patient security in terms of data protection. Hence, close collaborations between different actors, such as health care professionals, health technology companies, and health politicians, must be ensured [15]. Once such a system is running, both patients and health care professionals can benefit from better allocation of resources and adequate care, all with reduced risk of exposure. Telemedicine and digital technologies such as apps can also play larger roles in the present crisis not only to fight COVID-19 but also to address the frequent health issues associated with isolation or quarantine, such as psychological needs [57], mental health conditions [58], and physical inactivity 
[59]. Lastly, some developing countries face major obstacles to the effective delivery of digital health solutions in rural and remote locations, such as incomplete or insufficient basic digital infrastructures (eg, computers, internet networks, and electricity), lack of sustainable funding to develop, operate, and maintain digital platforms, and high telecommunication costs $[4,60,61]$.

\section{Recommendations to Improve Future Digital Health Systems}

In France, where the COVID-19 epidemic is growing at a rapid pace, the health technology ecosystem has rapidly and generously contributed to management of the crisis. Numerous telemedicine and telemonitoring platforms have been locally deployed in hospitals or general practices. However, a lack of coordination between operators has led to issues such as an absence of consensus about the symptoms to monitor and the alert systems to establish. We could argue that some telemonitoring is better than no monitoring; however, given the rapidly evolving body of knowledge around COVID-19, more transparent communication and greater comparability should be pursued to rapidly and homogeneously update the different solutions. Otherwise, some populations will lose the opportunity to gather this data and later use it for research or evaluation.

In previous emergency situations such as the Ebola virus outbreak, Hurricane Harvey, and Hurricane Irma, as well as currently during the COVID-19 pandemic, telehealth has been explored to support patient-physician communication and, hence, improved health outcomes. It must be ensured that outside of emergency situations, telehealth will be appropriately implemented into national health care systems in the long term. This would facilitate use of telehealth systems during outbreaks [62]. Germany is an example of a country where early implementation of telemedicine and mobile apps into the health care sector since 2018 have shown short-term benefits during the COVID-19 pandemic [63]. The German health ministry even claims that they now aim to accelerate the digitization of health care in Germany and help to translate new laws into practical solutions.

Digital initiatives to fight COVID-19 should be relevant to both hospital and public health systems, adapted to the population, rapidly deployable, and capable of evolving with the growth of the body of knowledge related to COVID-19. Regarding common standards for data collection in digital COVID-19 solutions, future initiatives should consider the example of ISARIC (the International Severe Acute Respiratory and emerging Infection Consortium [64]), who successfully organized clinical research on COVID-19 by providing standardized but customizable clinical research forms in several languages, ensuring a harmonized core set of international and comparable data, or the DP-3T initiative, an open implementation of a decentralized privacy-preserving proximity tracing solution [65].

\section{Conclusion}

Time is key to fight COVID-19, and digital health solutions provide the opportunity to buy time and human resources. As the COVID-19 pandemic is the first true global health crisis in the digital era, we have observed and will observe a plethora of digital solutions. This pandemic has at least demonstrated the usefulness and reactivity of digital health solutions and constitutes an opportunity to insert these solutions into our health care systems in the long term. This creates an urgent need for policy makers, researchers, and health professionals to collectively and efficiently implement digital solutions into practice without further fragmenting the existing landscapes of care. We now call for more concerted measures to have an optimal impact on the epidemic and to address the most strategic needs to ease the life of people who are at the forefront of the COVID-19 crisis [66].

\section{Acknowledgments}

GF and LH are supported by the Luxembourg National Research Fund (FNR) (Predi-COVID, Grant Number 14716273).

\section{Conflicts of Interest}

None declared.

\section{References}

1. Zhu N, Zhang D, Wang W, Li X, Yang B, Song J, China Novel Coronavirus Investigating and Research Team. A Novel Coronavirus from Patients with Pneumonia in China, 2019. N Engl J Med 2020 Feb 20;382(8):727-733 [FREE Full text] [doi: 10.1056/NEJMoa2001017] [Medline: 31978945]

2. World Health Organization. 2020 Mar 07. Responding to community spread of COVID-19: interim guidance, 7 March 2020 URL: https://apps.who.int/iris/handle/10665/331421 [accessed 2020-06-08]

3. Lipsitch M, Swerdlow DL, Finelli L. Defining the Epidemiology of Covid-19 - Studies Needed. N Engl J Med 2020 Mar 26;382(13):1194-1196. [doi: 10.1056/NEJMp2002125] [Medline: 32074416]

4. Mahmood S, Hasan K, Colder Carras M, Labrique A. Global Preparedness Against COVID-19: We Must Leverage the Power of Digital Health. JMIR Public Health Surveill 2020 Apr 16;6(2):e18980 [FREE Full text] [doi: 10.2196/18980] [Medline: 32297868]

5. Center for Systems Science and Engineering at Johns Hopkins University. COVID-19 Dashboard URL: https://coronavirus. jhu.edu/map.html [accessed 2020-04-21] 
6. Reeves JJ, Hollandsworth HM, Torriani FJ, Taplitz R, Abeles S, Tai-Seale M, et al. Rapid response to COVID-19: health informatics support for outbreak management in an academic health system. J Am Med Inform Assoc 2020 Jun 01;27(6):853-859 [FREE Full text] [doi: 10.1093/jamia/ocaa037] [Medline: 32208481]

7. Power B. The Washington Post. 2020 Mar 27. The coronavirus is expanding the surveillance state. How will this play out? URL: https://www.washingtonpost.com/politics/2020/03/27/

coronavirus-is-expanding-surveillance-state-how-will-this-play-out/ [accessed 2020-04-21]

8. Ohannessian R, Duong TA, Odone A. Global Telemedicine Implementation and Integration Within Health Systems to Fight the COVID-19 Pandemic: A Call to Action. JMIR Public Health Surveill 2020 Apr 02;6(2):e18810 [FREE Full text] [doi: 10.2196/18810] [Medline: $\underline{32238336]}$

9. Pérez Sust P, Solans O, Fajardo JC, Medina Peralta M, Rodenas P, Gabaldà J, et al. Turning the Crisis Into an Opportunity: Digital Health Strategies Deployed During the COVID-19 Outbreak. JMIR Public Health Surveill 2020 May 04;6(2):e19106 [FREE Full text] [doi: 10.2196/19106] [Medline: 32339998]

10. Greenhalgh T, Wherton J, Shaw S, Morrison C. Video consultations for covid-19. BMJ 2020 Mar 12;368:m998. [doi: 10.1136/bmj.m998] [Medline: 32165352]

11. Greenhalgh T, Koh GCH, Car J. Covid-19: a remote assessment in primary care. BMJ 2020 Mar 25;368:m1182. [doi: 10.1136/bmj.m1182] [Medline: 32213507]

12. Hong Z, Li N, Li D, Li J, Li B, Xiong W, et al. Telemedicine During the COVID-19 Pandemic: Experiences From Western China. J Med Internet Res 2020 May 08;22(5):e19577 [FREE Full text] [doi: 10.2196/19577] [Medline: 32349962]

13. Wang C, Sarsenbayeva Z, Chen X, Dingler T, Goncalves J, Kostakos V. Accurate Measurement of Handwash Quality Using Sensor Armbands: Instrument Validation Study. JMIR Mhealth Uhealth 2020 Mar 26;8(3):e17001 [FREE Full text] [doi: 10.2196/17001] [Medline: 32213469]

14. Gong K, Xu Z, Cai Z, Chen Y, Wang Z. Internet Hospitals Help Prevent and Control the Epidemic of COVID-19 in China: Multicenter User Profiling Study. J Med Internet Res 2020 Apr 14;22(4):e18908 [FREE Full text] [doi: 10.2196/18908] [Medline: 32250962]

15. Hollander JE, Carr BG. Virtually Perfect? Telemedicine for Covid-19. N Engl J Med 2020 Apr 30;382(18):1679-1681. [doi: 10.1056/NEJMp2003539] [Medline: 32160451]

16. HealthManagement. COVID-19: What Can Healthcare Learn? URL: https://healthmanagement.org/c/healthmanagement/ issuearticle/covid-19-what-can-healthcare-learn [accessed 2020-04-22]

17. maladiecoronavirus.fr. URL: https://maladiecoronavirus.fr/ [accessed 2020-06-08]

18. Beat COVID-19 Now. URL: https://beatcovid19now.org/ [accessed 2020-06-08]

19. Martin A, Nateqi J, Gruarin S, Munsch N, Abdarahmane I, Knapp B. An artificial intelligence based first-line defence against COVID-19: digitally screening citizens for risks via a chatbot Internet. bioaRxiv 2020 Apr 06:preprint. [doi: $10.1101 / 2020.03 .25 .008805]$

20. Wetsman N. The Verge. 2020 Mar 04. Effective communication is critical during emergencies like the COVID-19 outbreak URL: https://www.theverge.com/2020/3/4/21164563/coronavirus-risk-communication-cdc-trump-trust [accessed 2020-04-21]

21. World Health Organization. 2020 Mar 27. Mental health and psychological resilience during the COVID-19 pandemic URL: http://www.euro.who.int/en/health-topics/health-emergencies/coronavirus-covid-19/news/news/2020/3/ mental-health-and-psychological-resilience-during-the-covid-19-pandemic [accessed 2020-04-21]

22. World Health Organization. WHO Health Alert brings COVID-19 facts to billions via WhatsApp URL: https://www.who.int/ news-room/feature-stories/detail/who-health-alert-brings-covid-19-facts-to-billions-via-whatsapp [accessed 2020-04-21]

23. ICTworks. 2017 Jan 25. How We Fought Ebola with Information - ICTworks Internet URL: https://www.ictworks.org/ how-we-fought-ebola-with-information/ [accessed 2020-04-21]

24. Ni MY, Yang L, Leung CMC, Li N, Yao XI, Wang Y, et al. Mental Health, Risk Factors, and Social Media Use During the COVID-19 Epidemic and Cordon Sanitaire Among the Community and Health Professionals in Wuhan, China: Cross-Sectional Survey. JMIR Ment Health 2020 May 12;7(5):e19009 [FREE Full text] [doi: 10.2196/19009] [Medline: 32365044]

25. Ryan G, De Silva M, Terver JS, Ochi OP, Eaton J. Information systems for global mental health. Lancet Psychiat 2015 May;2(5):372-373. [doi: 10.1016/S2215-0366(15)00097-8] [Medline: 26360265]

26. Basu M. GovInsider. 2020 Mar 03. Exclusive: How Singapore sends daily Whatsapp updates on coronavirus URL: https:/ /govinsider.asia/innovation/singapore-coronavirus-whatsapp-covid19-open-government-products-govtech/ [accessed 2020-04-21]

27. ReliefWeb. 2020 Mar 15. COVID-19: How to include marginalized and vulnerable people in risk communication and community engagement - World Internet URL: https://reliefweb.int/report/world/ covid-19-how-include-marginalized-and-vulnerable-people-risk-communication-and [accessed 2020-04-21]

28. Signorini A, Segre AM, Polgreen PM. The use of Twitter to track levels of disease activity and public concern in the U.S. during the influenza A H1N1 pandemic. PLoS One 2011 May 04;6(5):e19467 [FREE Full text] [doi: 10.1371/journal.pone.0019467] [Medline: 21573238] 
29. Du J, Tang L, Xiang Y, Zhi D, Xu J, Song H, et al. Public Perception Analysis of Tweets During the 2015 Measles Outbreak: Comparative Study Using Convolutional Neural Network Models. J Med Internet Res 2018 Jul 09;20(7):e236 [FREE Full text] [doi: 10.2196/jmir.9413] [Medline: 29986843]

30. Stefanidis A, Vraga E, Lamprianidis G, Radzikowski J, Delamater PL, Jacobsen KH, et al. Zika in Twitter: Temporal Variations of Locations, Actors, and Concepts. JMIR Public Health Surveill 2017 Apr 20;3(2):e22 [FREE Full text] [doi: 10.2196/publichealth.6925] [Medline: 28428164]

31. Liang H, Fung IC, Tse ZTH, Yin J, Chan C, Pechta LE, et al. How did Ebola information spread on twitter: broadcasting or viral spreading? BMC Public Health 2019 Apr 25;19(1):438 [FREE Full text] [doi: 10.1186/s12889-019-6747-8] [Medline: 31023299]

32. Morin C, Bost I, Mercier A, Dozon J, Atlani-Duault L. Information Circulation in times of Ebola: Twitter and the Sexual Transmission of Ebola by Survivors. PLoS Curr 2018 Aug 28;10:E1 [FREE Full text] [doi:

10.1371/currents.outbreaks.4e35a9446b89c1b46f8308099840d48f] [Medline: 30254789$]$

33. Tang L, Bie B, Park S, Zhi D. Social media and outbreaks of emerging infectious diseases: A systematic review of literature. Am J Infect Control 2018 Sep;46(9):962-972 [FREE Full text] [doi: 10.1016/j.ajic.2018.02.010] [Medline: 29628293]

34. Ayyoubzadeh SM, Ayyoubzadeh SM, Zahedi H, Ahmadi M, R Niakan Kalhori S. Predicting COVID-19 Incidence Through Analysis of Google Trends Data in Iran: Data Mining and Deep Learning Pilot Study. JMIR Public Health Surveill 2020 Apr 14;6(2):e18828 [FREE Full text] [doi: 10.2196/18828] [Medline: 32234709]

35. Li C, Chen LJ, Chen X, Zhang M, Pang CP, Chen H. Retrospective analysis of the possibility of predicting the COVID-19 outbreak from Internet searches and social media data, China, 2020. Euro Surveill 2020 Mar;25(10):pii=2000199 [FREE Full text] [doi: 10.2807/1560-7917.ES.2020.25.10.2000199] [Medline: 32183935]

36. Tricco AC, Zarin W, Lillie E, Jeblee S, Warren R, Khan PA, et al. Utility of social media and crowd-intelligence data for pharmacovigilance: a scoping review. BMC Med Inform Decis Mak 2018 Jun 14;18(1):38 [FREE Full text] [doi: 10.1186/s12911-018-0621-y] [Medline: 29898743]

37. Alessa A, Faezipour M. Flu Outbreak Prediction Using Twitter Posts Classification and Linear Regression With Historical Centers for Disease Control and Prevention Reports: Prediction Framework Study. JMIR Public Health Surveill 2019 Jun 25;5(2):e12383 [FREE Full text] [doi: 10.2196/12383] [Medline: 31237567]

38. Viboud C, Santillana M. Fitbit-informed influenza forecasts. Lancet Digital Health 2020 Feb;2(2):e54-e55 [FREE Full text] [doi: 10.1016/s2589-7500(19)30241-9]

39. Luo X, Zimet G, Shah S. A natural language processing framework to analyse the opinions on HPV vaccination reflected in twitter over 10 years (2008 - 2017). Hum Vaccin Immunother 2019;15(7-8):1496-1504. [doi: 10.1080/21645515.2019.1627821] [Medline: 31194609]

40. Abd-Alrazaq A, Alhuwail D, Househ M, Hamdi M, Shah Z. Top Concerns of Tweeters During the COVID-19 Pandemic: Infoveillance Study. J Med Internet Res 2020 Apr 21;22(4):e19016 [FREE Full text] [doi: 10.2196/19016] [Medline: 32287039]

41. Kouzy R, Abi Jaoude J, Kraitem A, El Alam MB, Karam B, Adib E, et al. Coronavirus Goes Viral: Quantifying the COVID-19 Misinformation Epidemic on Twitter. Cureus 2020 Mar 13;12(3):e7255 [FREE Full text] [doi: 10.7759/cureus.7255] [Medline: 32292669]

42. Pennycook G, McPhetres J, Zhang Y, Rand D. Fighting COVID-19 misinformation on social media: Experimental evidence for a scalable accuracy nudge intervention. PsyArXiv 2020 Mar 17:preprint [FREE Full text] [doi: 10.31234/osf.io/uhbk9]

43. Park HW, Park S, Chong M. Conversations and Medical News Frames on Twitter: Infodemiological Study on COVID-19 in South Korea. J Med Internet Res 2020 May 05;22(5):e18897 [FREE Full text] [doi: 10.2196/18897] [Medline: 32325426]

44. Pan X. Application of personal-oriented digital technology in preventing transmission of COVID-19, China. Ir J Med Sci 2020 Mar 27:1-2 [FREE Full text] [doi: 10.1007/s11845-020-02215-5] [Medline: 32219674]

45. Mackert M, Mabry-Flynn A, Champlin S, Donovan EE, Pounders K. Health Literacy and Health Information Technology Adoption: The Potential for a New Digital Divide. J Med Internet Res 2016 Oct 04;18(10):e264 [FREE Full text] [doi: 10.2196/jmir.6349] [Medline: 27702738]

46. Sim I. Mobile Devices and Health. N Engl J Med 2019 Sep 05;381(10):956-968. [doi: 10.1056/NEJMra1806949] [Medline: 31483966]

47. Gamble A, Pham Q, Goyal S, Cafazzo JA. The Challenges of COVID-19 for People Living With Diabetes: Considerations for Digital Health. JMIR Diabetes 2020 May 15;5(2):e19581 [FREE Full text] [doi: 10.2196/19581] [Medline: 32392473 ]

48. Nguyen A, Mosadeghi S, Almario CV. Persistent digital divide in access to and use of the Internet as a resource for health information: Results from a California population-based study. Int J Med Inform 2017 Jul;103:49-54. [doi:

10.1016/j.ijmedinf.2017.04.008] [Medline: 28551001]

49. Ferretti L, Wymant C, Kendall M, Zhao L, Nurtay A, Abeler-Dörner L, et al. Quantifying SARS-CoV-2 transmission suggests epidemic control with digital contact tracing. Science 2020 May 08;368(6491):eabb6936 [FREE Full text] [doi: 10.1126/science.abb6936] [Medline: 32234805]

50. Payments News \& Mobile Payments Trends. 2020 Mar 25. App Lets Singapore Track Virus Patients' Movements URL: https://www.pymnts.com/coronavirus/2020/app-lets-singapore-track-virus-patients-movements/ [accessed 2020-04-22] 
51. Aron M. L'Obs. 2020 Mar 26. «CoronApp », une application française pour géolocaliser les porteurs du coronavirus URL: https://www.nouvelobs.com/coronavirus-de-wuhan/20200326.OBS26600/ coronapp-une-application-francaise-pour-geolocaliser-les-porteurs-du-virus-covid-19.html [accessed 2020-04-22]

52. Jee C. MIT Technology Review. 2020 Mar 25. A new app might help researchers monitor the spread of coronavirus URL: https://www.technologyreview.com/2020/03/25/950310/a-new-app-might-help-researchers-monitor-the-spread-of-coronavirus/ [accessed 2020-04-22]

53. Abeler J, Bäcker M, Buermeyer U, Zillessen H. COVID-19 Contact Tracing and Data Protection Can Go Together. JMIR Mhealth Uhealth 2020 Apr 20;8(4):e19359 [FREE Full text] [doi: 10.2196/19359] [Medline: 32294052]

54. Ekong I, Chukwu E, Chukwu M. COVID-19 Mobile Positioning Data Contact Tracing and Patient Privacy Regulations: Exploratory Search of Global Response Strategies and the Use of Digital Tools in Nigeria. JMIR Mhealth Uhealth 2020 Apr 27;8(4):e19139 [FREE Full text] [doi: 10.2196/19139] [Medline: 32310817]

55. GitHub. DP-3T Documents URL: https://github.com/DP-3T/documents [accessed 2020-05-15]

56. Keesara S, Jonas A, Schulman K. Covid-19 and Health Care's Digital Revolution. N Engl J Med 2020 Apr 02:e82 [FREE Full text] [doi: 10.1056/nejmp2005835]

57. Liu S, Yang L, Zhang C, Xiang Y, Liu Z, Hu S, et al. Online mental health services in China during the COVID-19 outbreak. Lancet Psychiat 2020 Apr;7(4):e17-e18 [FREE Full text] [doi: 10.1016/S2215-0366(20)30077-8] [Medline: 32085841]

58. Zhou X, Snoswell CL, Harding LE, Bambling M, Edirippulige S, Bai X, et al. The Role of Telehealth in Reducing the Mental Health Burden from COVID-19. Telemed J E Health 2020 Apr;26(4):377-379. [doi: 10.1089/tmj.2020.0068] [Medline: 32202977]

59. Torous J, Jän Myrick K, Rauseo-Ricupero N, Firth J. Digital Mental Health and COVID-19: Using Technology Today to Accelerate the Curve on Access and Quality Tomorrow. JMIR Ment Health 2020 Mar 26;7(3):e18848 [ㅌREE Full text] [doi: 10.2196/18848] [Medline: 32213476]

60. Muinga N, Magare S, Monda J, English M, Fraser H, Powell J, et al. Digital health Systems in Kenyan Public Hospitals: a mixed-methods survey. BMC Med Inform Decis Mak 2020 Jan 06;20(1):2 [FREE Full text] [doi: 10.1186/s12911-019-1005-7] [Medline: 31906932]

61. Kruse C, Betancourt J, Ortiz S, Valdes Luna SM, Bamrah IK, Segovia N. Barriers to the Use of Mobile Health in Improving Health Outcomes in Developing Countries: Systematic Review. J Med Internet Res 2019 Oct 09;21(10):e13263 [FREE Full text] [doi: 10.2196/13263] [Medline: 31593543]

62. Smith AC, Thomas E, Snoswell CL, Haydon H, Mehrotra A, Clemensen J, et al. Telehealth for global emergencies: Implications for coronavirus disease 2019 (COVID-19). J Telemed Telecare 2020 Mar 20:1357633X20916567 [FREE Full text] [doi: 10.1177/1357633X20916567] [Medline: 32196391]

63. Olesch A. Healthcare IT News. 2020 Mar 26. Germany benefits from digital health infrastructure during COVID-19 pandemic URL: https://www.healthcareitnews.com/news/europe/

germany-benefits-digital-health-infrastructure-during-covid-19-pandemic [accessed 2020-04-21]

64. International Severe Acute Respiratory and emerging Infection Consortium. COVID-19 New: Clinical data report URL: https://isaric.tghn.org/ [accessed 2020-04-21]

65. GitHub. DP^3T URL: https://github.com/DP-3T [accessed 2020-04-21]

66. Call for papers: COVID-19 research rapidly peer-reviewed and published in JMIR journals. JMIR Publications. URL: https://www.jmir.org/announcement/view/202 [accessed 2020-06-16]

\section{Abbreviations}

CDC: US Centers for Disease Control and Prevention

COVID-19: coronavirus disease

DP-3T: Decentralized Privacy-Preserving Proximity Tracing

e-prescription: electronic prescription

ISARIC: International Severe Acute Respiratory and emerging Infection Consortium

MERS: Middle East respiratory syndrome

SARS: severe acute respiratory syndrome

WHO: World Health Organization 
Edited by G Eysenbach; submitted 11.04.20; peer-reviewed by SM Ayyoubzadeh, C Auschra; comments to author 20.04.20; revised version received 22.04.20; accepted 04.06.20; published 16.06.20

Please cite as:

Fagherazzi G, Goetzinger C, Rashid MA, Aguayo GA, Huiart L

Digital Health Strategies to Fight COVID-19 Worldwide: Challenges, Recommendations, and a Call for Papers

$J$ Med Internet Res 2020;22(6):e19284

URL: http://www.jmir.org/2020/6/e19284/

doi: $10.2196 / 19284$

PMID: 32501804

(C) Guy Fagherazzi, Catherine Goetzinger, Mohammed Ally Rashid, Gloria A Aguayo, Laetitia Huiart. Originally published in the Journal of Medical Internet Research (http://www.jmir.org), 16.06.2020. This is an open-access article distributed under the terms of the Creative Commons Attribution License (https://creativecommons.org/licenses/by/4.0/), which permits unrestricted use, distribution, and reproduction in any medium, provided the original work, first published in the Journal of Medical Internet Research, is properly cited. The complete bibliographic information, a link to the original publication on http://www.jmir.org/, as well as this copyright and license information must be included. 